\title{
UPAYA PENINGKATAN KINERJA GURU \\ MELALUI TEKNIK LESSON STUDY SECARA \\ KOLABORATIF DAN RUTIN DI TK PURI INSANI KOTA JAMBI
}

\author{
Roslimar \\ TK Puri Insani Kota Jambi \\ Email: $\underline{\text { roslimarrosjambi@gmail.com }}$
}

\begin{abstract}
ABSTRAK
Tuntutan masyarakat saat ini adalah pendidikan yang bermutu, sekolah dituntut memperbaiki atau meningkatkan pencitraan publik sehingga masyarakat yakin bahwa sekolah tersebut layak menjadi pilihan putra-putrinya. Lesson study dengan karakteristiknya nampaknya dapat digunakan sebagai salah satu alternatif untuk mengatasi masalah tersebut sehingga pencitraan publik sekolah meningkat.

Memang Lesson Study banyak menekankan pada pembelajaran di kelas namun dampak kegiatan ini bisa pada aspek yang lain misal: peningkatan sarana pembelajaran, inovasi sekolah, perubahan visi dan misi sekolah, motivasi guru dan pimpinan sekolah, serta muncul aktivitas ekstrakurikuler dan lain-lain.

Lesson study berbasis sekolah yang dilakukan secara rutin akan muncul inovasi pada sekolah sehingga dapat digunakan sebagai upaya memperbaiki citra publik sekolah, kegiatan bisa berlangsung dengan baik perlu adanya komitmen kepala sekolah dan kemauan guru untuk memperbaiki diri.
\end{abstract}

Kata kunci: Kinerja Guru, Teknik Pembelajaran, Lesson Study 


\section{A. PENDAHULUAN}

\section{Latar Belakang}

Salah satu persoalan pendidikan yang sedang dihadapi bangsa kita adalah persoalan mutu pendidikan pada setiap jenjang dan satuan pendidikan. Berbagai usaha telah dilakukan untuk meningkatkan mutu pendidikan nasional, antara lain melalui berbagai pelatihan dan peningkatan kompetensi guru, pengadaan buku dan alat pelajaran, perbaikan sarana dan prasarana pendidikan, dan meningkatkan mutu manajemen sekolah. Namun demikian, indikator mutu pendidikan belum menunjukkan peningkatan yang berarti. Sebagian sekolah, terutama di kota-kota, menunjukkan peningkatan mutu pendidikan yang cukup menggembirakan, sebagian besar lainnya masih memprihatinkan.

Dalam upaya meningkatkan mutu pendidikan nasional, pemerintah khususnya melalui Departemen Pendidikan Nasional terus menerus berupaya melakukan berbagai perubahan dan pembaharuan sistem pendidikan kita. Salah satu upaya yang sudah dan sedang dilakukan, yaitu berkaitan dengan faktor guru. Lahirnya Undang-Undang No. 14 tahun 2005 tentang Guru dan Dosen dan Peraturan Pemerintah No. 19 Tahun 2005 tentang Standar Nasional Pendidikan, pada dasarnya merupakan kebijakan pemerintah yang di dalamnya memuat usaha pemerintah untuk menata dan memperbaiki mutu guru di Indonesia. Michael G. Fullan yang dikutip oleh Suyanto dan Djihad Hisyam (2000) mengemukakan bahwa "educational change depends on what teachers do and think...". Pendapat tersebut mengisyaratkan bahwa perubahan dan pembaharuan sistem pendidikan sangat bergantung pada "what teachers do and think", atau dengan kata lain bergantung pada penguasaan kompetensi guru.

Jika kita amati lebih jauh tentang realita kompetensi guru saat ini agaknya masih beragam. Sudarwan Danim (2002) mengungkapkan bahwa salah satu ciri krisis pendidikan di Indonesia adalah guru belum mampu menunjukkan kinerja (work performance) yang memadai. Hal ini menunjukkan bahwa kinerja guru belum sepenuhnya ditopang oleh derajat penguasaan kompetensi yang memadai, oleh karena itu perlu adanya upaya yang komprehensif guna meningkatkan kompetensi guru. 
Berdasarkan masalah di atas, maka berbagai pihak mempertanyakan apa yang salah dalam penyelenggaraan pendidikan kita? Kurangnya pemahaman guru akan tugasnya sebagai agen pembelajaran, merupakan salah satu faktor rendahnya mutu pembelajaran. Guru sebagai agen pembelajaran harus memiliki beberapa kompetensi diantaranya adalah kompetensi kepribadian, kompetensi pedagogik, kompetensi profesional, dan kompetensi sosial. Apabila guru mampu menguasai kompetensi tersebut maka mutu pendidikan akan meningkat.

Dari uraian di atas, penulis selaku kepala sekolah melakukan terobosan untuk menyikapi sekaligus memperbaiki pola-pola pemikiran yang salah dengan memberikan pengarahan/ pembinaan guru berbasis sekolah yang dinamakan dengan (Lesson Study) secara kolaboratif dan berkelanjutan berlandaskan prinsip-prinsip kolegalitas dan mutual learning untuk membangun komunitas belajar, untuk membekali guru dalam melaksanakan tugasnya sebagai agen pembelajaran. Kata kuncinya adalah "rutinitas" penulis mempunyai keyakinan bahwa dengan pengarahan secara rutin, terprogram dengan baik dan kontrol terhadap persiapan guru sebelum melaksanakan tugas mengajar di kelas maka akan terbentuk tenaga pendidik yang produktif/ profesional dan mampu meningkatkan mutu pembelajaran. Memang, dalam awal-awal pelaksanaan program ini ada beberapa diantara guru yang menunjukkan sikap acuh tak acuh, tetapi dengan kesabaran dan ketekunan akhirnya guru tersebut sangat antusias setelah merasakan dampak dan manfaat yang dapat dipetik dari pelaksanaan program tersebut.

Hubungan kepala sekolah dengan guru-guru harus baik, tanggung jawab, didasari dengan kejujuran, kesetiaan, keikhlasan dan kerjasama. Apabila diibaratkan dalam satu keluarga, maka hubungan Kepala Sekolah dengan guruguru lainnya harus beriangsung bagaikan hubungan satu saudara dengan saudara lainnya, dan hubungan kepala sekolah dengan siswa harus seperti hubungan ayah dengan anak.

Maka berdasarkan latar belakang tersebut penulis melakukan upaya perbaikan untuk meningkatkan mutu pembelajaran di Sekolah Taman Kanak- 
kanak PURI INSANI Kecamatan Kota Baru Kota Jambi melalui Penelitian Tindakan Sekolah (PTS) dengan judul: "Upaya Peningkatan Kinerja Guru Melalui Teknik Lesson Study Secara Kolaboratif dan Rutin Di Taman Kanak-kanak Puri Insani Kota Jambi"

\section{Rumusan Masalah}

Dalam Penelitian Tindakan Sekolah ini penulis merumuskan masalah sebagai berikut:

1) Bagaimana perencanaan guru dalam melaksanakan tugas mengajar agar mutu pembelajaran meningkat?

2) Bagaimana pemahaman guru terhadap tugasnya sebagai agen pembelajaran?

3) Bagaimana guru menerapkan teknik praktek rencana pembelajaran di kelas untuk meningkatkan mutu pembelajaran?

4) Apakah tingkat kesadaran dan tanggung jawab guru sebagai pendidik sudah seimbang dengan tugas pokok dan fungsi yang dibebankan oleh pemerintah?

\section{Tujuan}

Secara khusus tujuan penelitian dirumuskan sebagai berikut:

a. Meningkatkan kesadaran dan tanggung jawab guru akan tugas pokok dan fungsinya yang dibebankan oleh orang tua, masyarakat dan pemerintah.

b. Menyusun dan mengevaluasi perencanaan guru dalarn melaksanakan tugas mengajar agar mutu pembelajaran meningkat.

c. Meningkatkan pemahaman guru terhadap tugasnya sebagai agen pembelajaran.

d. Membentuk dan menciptakan disiplin kerja serta iklim budaya kerja sekolah untuk meningkatkan mutu pembelajaran.

\section{Manfaat}

a. Manfaat Teoritis

Melalui kegiatan penelitian ini diperoleh alternatif solusi dalam 
meningkatkan kemampuan guru untuk meningkatkan mutu pembelajaran di kelas b. Manfaat Praktis

1. Bagi Guru

- Memikirkan secara lebih teliti lagi tentang tujuan, materi tertentu yang akan dibelajarkan kepada siswa.

- Memikirkan secara mendalam tentang tujuan-tujuan pembelajaran untuk kepentingan masa depan siswa, misalnya tentang arti penting sebuah persahabatan, pengembangan perspektif dan cara berfikir siswa, serta kegandrungan siswa terhadap ilmu pengetahuan.

- Mengkaji tentang hal-hal terbaik yang dapat digunakan dalam pembelajaran melalui belajar dari para guru lain (peserta atau partisipan lesson study),

- Belajar tentang isi atau materi pelajaran dari guru lain sehingga dapat menambah pengetahuan tentang apa yang harus diberikan kepada siswa.

- Mengembangkan keahlian dalam mengajar, baik pada saat merencanakan maupun selama berlangsungnya kegiatan pembelajaran,

2. Manfaat bagi Sekolah

Penelitian ini diharapkan dapat memberikan umpan balik bagi pembinaan dan pengembangan kompetensi guru untuk meningkatkan mutu pembelajaran dan pendidikan.

3. Manfaat Bagi Siswa

Siswa akan menikmati pembelajaran yang lebih tertib dan bermutu karena guru telah mempersiapkan segala sesuatunya dengan baik.

\section{B. KAJIAN TEORITIS}

\section{Tugas Pokok Kepala Sekolah}

Tugas pokok Kepala Sekolah adalah merencanakan, melaksanakan program manajamen sekolah termasuk memantau, menilai mensupervisi, membina, dan melaporkan terhadap kinerja guru dalam pembelajaran, kinerja sekolah dalam mengelola pendidikan. Sofyan Salim (2007) tugas yang harus dilakukan Kepala Sekolah adalah melakukan pembinaan pengembangan 
kualitas sekolah, kinerja sekolah, kinerja guru dan kinerja seluruh staf sekolah. Kepala sekolah managerial pada dasarnya memberikan pembinaan, penilaian dan bantuan/ bimbingan mulai dari rencana program, proses dan sampai dengan hasil.

Fungsi Kepala Sekolah adalah sebagai mitra guru, pembaru (inovator), penyuluh (konselor), pendorong (motivator), kerjasama (kolabolator), penilaian (asesor), konsultan didalam melaksanakan tugas pokok dan tanggung jawabnya terhadap kinerja guru dalam pembelajaran dan kinerja kepala sekolah dalam mengelola pendidikan.

Salim (2007) mengemukakan Kepala Sekolah satuan pendidikan melaksanakan fungsi-fungsi supervisi, baik supervisi akademik maupun supervisi manajerial. Adapun sasaran supervisi akademik antara lain membantu guru dalam merencanakan kegiatan pembelajaran dan atau bimbingan, mengembangkan interaksi pembelajaran (metode, strategi, teknik, model, pendekatan dan lain-lain) yang tepat guna.

Manajemen pendidikan merupakan proses pengembangan kegiatan kerjasama sekelompok orang untuk mencapai tujuan pendidikan yang telah ditetapkan. Proses pengendalian kegiatan kelompok tersebut mencakup perencanaan (planning), pengorganisasian (organizing), penggerakkan (actuating), dan pengawasan (controling) sebagai suatu proses untuk menjadikan visi menjadi aksi.(Sumarto, 2017)

Engkoswara $(2001 ; 2)$ mengemukakan bahwa manajemen pendidikan dalam arti seluas-luasnya adalah suatu ilmu yang mempelajari bagaimana menata sumber daya untuk mencapai tujuan yang telah ditetapkan secara produktif dan bagaimana menciptakan suasana yang baik bagi manusia yang turut serta dalam mencapai tujuan yang di sepakati bersama.

Lebih lanjut dikemukakan bahwa penataan mengandung makna mengatur, memimpin, mengelola atau mengadministrasikan sumber daya meliputi perencanaan, pelaksanaan, pengawasan, dan pembinaan. Sumber daya terdiri dan sumber daya manusia (peserta didik, pendidik, dan pemakai jasa pendidikan), sumber belajar dan kurikulum (segala sesuatu yang 7 
disediakan lembaga pendidikan untuk mencapai tujuan), serta fasilitas (peralatan, barang, dan keuangan yang menunjang kemungkinkan terjadinya pendidikan). Tujuan pendidikan yang produktif berupa prestasi yang efektif dan suasana atau proses efisien, sedangkan keberhasilan pencapaian tujuan pendidikan yang produktif dapat dilihat dari sudut administrative psikologis, dan ekonomis.

\section{Peran Kepala Sekolah}

Agar proses pendidikan dapat berjalan efektif dan efisien, guru dituntut memiliki kompetensi yang memadai, baik dari segi jenis maupun isinya. Namun, jika kita selami lebih dalam lagi tentang isi yang terkandung dari setiap jenis kompetensi, sebagaimana disampaikan oleh para ahli maupun dalam perspektif kebijakan pemerintah, kiranya untuk menjadi guru yang kompeten bukan sesuatu yang sederhana. Untuk mewujudkan dan meningkatkan kompetensi guru diperlukan upaya yang sungguh-sungguh dan komprehensif.(Hidayat \& Sumarto, 2018).

Salah satu upaya yang dapat dilakukan adalah melalui optimalisasi peran kepala sekolah. Idochi Anwar dan Yayat Hidayat Amir (2000) mengemukakan bahwa "kepala sekolah sebagai pengelola memiliki tugas mengembangkan kinerja personel, terutama meningkatkan kompetensi profesional guru." Dalam perspektif kebijakan pendidikan nasional (Depdiknas, 2006), terdapat tujuh peran utama kepala sekolah yaitu, sebagai:(1) educator (pendidik); (2) manajer; administrator; (4) supervisor (penyelia); (5) leader (pemimpin); (6) pencipta iklim kerja; dan (7) wirausahawan;

\section{Lesson Study Dalam Kegiatan Pembelajaran}

Lesson Study merupakan model pembinaan profesi pendidik melalui pengkajian pembelajaran secara kolaboratif dan berkelanjutan berlandaskan prinsip-prinsip kolegalitas dan mutual learning untuk membangun komunitas belajar.

Lesson Study adalah program yang diterapkan oleh SISTTEMS, (Strengthening In-Service Teacher Training of Mathematics and Science Education at Junior Secondary Level) yaitu bentuk kerjasama antara JICA 
(Japan International Cooperation Agency) dan MONE / Depdiknas (Ministry of National Education / Departemen Pendidikan Nasional) Indonesia.

Lesson Study bukan merupakan metoda atau strategi pembelajaran tetapi kegiatan yang dapat menerapkan berbagai metoda dan strategi pembelajaran yang sesuai dengan situasi, kondisi, kemampuan komunitas pembelajaran serta berbagai permasalahan yang dihadapi dalam kegiatan pembelajaran. Lesson Study adalah metode yang berorientasi pada praktek untuk meningkatkan keterampilan mengajar oleh guru-guru itu sendiri.

\section{Teknik Lesson Study}

Lesson Study biasanya terdiri dari tahapan-tahapan berikut:

a. Guru mempersiapkan rencana pembelajaran (PLAN-tahap perencanaan),

b. Salah seorang guru mempraktekkan rencana pembelajaran di kelas yang sesungguhnya, sedangkan para guru pendamping yang lain dan kepala sekolah mengamati pembelajaran tersebut (DO-tahap pembelajaran terbuka),

c. Setelah pembelajaran, guru pengajar dan para guru pengamat mendiskusikan hasil pembelajaran, kemudian disampaikan kepada kepala sekolah untuk menyampaikan umpan balik pada guru pengajar.

Istilah yang digunakan untuk metode sejenis ini diberbagai sumber pustaka, misalnya: "action research", "coaching", dan "clinical supervision". Dalam program ini, lesson study akan digunakan sebagai istilah umum untuk kegiatan yang berusaha untuk mengembangkan profesi guru. Revolusi pembelajaran yang dilakukan melalui kegiatan Lesson Study telah menunjukkan hasil yang luar biasa. Indikator keberhasilannya itu dapat dilihat diantaranya:

1. Tumbuhnya semangat guru dalam mencari dan menerapkan berbagai metoda atau strategi pembelajaran. Hal ini dikarenakan setiap dilaksanakan implementasi Lesson Study, guru dituntut untuk memilih metoda atau strategi pembelajaran yang lain dari yang pernah dipakai dalam implementasiimplementasi sebelumnya.

2. Tumbuhnya prinsip kolegalitas diantara guru-guru mata pelajaran, khususnya yang sejenis. Hal ini ditunjukkan dengan semakin efektifnya kegiatan 
Musyawarah Guru Mata Pelajaran (MGMP). Sebelumnya, kegiatan MGMP itu, kalaupun ada, hanya terbatas bila menghadapi ujian nasional saja. Bahkan kegiatan MGMP pun biasanya diselenggarakan oleh sub rayon, bahkan rayon, yang tentu secara domisili kesulitan dijangkau oleh transportasi, terutama di sekolah-sekolah yang berada di pinggiran. Melalui kegiatan MOMP yang diselenggarakan di Base Camp, lebih mudah dijangkau oleh guru-guru anggota MOMP, sehingga silaturrahmi dan kolegalitas, sebagai ruh Lesson Study, dapat tercipta.

3. Dukungan moril dan materil dari pimpinan sekolah semakin kuat. Hal ini bisa dilihat pada setiap kegiatan Lesson Study melalui MGMP mendapat dukungan dari kepala sekolah. Bahkan hampir setiap kegiatan Lesson Study dihadiri langsung oleh kepala sekolah-kepala sekolah, khususnya dalam satu base camp. Tentunya, dengan dukungan yang besar dari pimpinan akan memberi motivasi bagi untuk mengikuti kegiatan MGMP. Tetapi sebaliknya, bila pimpinan sekolah tidak memberi motivasi, maka gurunya pun tidak akan semangat mengikuti kegiatan MGMP.

4. Guru mendapat banyak pencerahan, selain dari teman sejawat, juga dari para dosen pembimbing (fasilitator) yang setiap pertemuan selalu hadir untuk memberikan dukungan, baik ketika melakukan PLAN (perencanaan), DO (pelaksanaan/implementasi) dan SEE (refleksi).

Oleh karena itu, upaya untuk meningkatkan kegiatan Lesson Study agar berjalan lebih baik harus mendapat perhatian dan merupakan tugas dan tanggung jawab bersama, baik bagi guru-guru, kepala sekolah, dinas pendidikan dan Lembaga Pendidikan Tenaga Kependidikan (LPTK) yang terlibat langsung dengan kegiatan Lesson Study.

\section{METODE PENELITIAN}

\section{Pendekatan Penelitian}

Sebagai mekanisme penelitian yang dapat menggambarkan tercapainya tujuan yang telah ditetapkan maka ditempuhlah prosedur penelitian tindakan sekolah ini dengan menggunakan pendekatan penelitian kualitatif.

\section{Teknik Analisis Data}


Setelah seluruh data yang diperlukan maka langkah selanjutnya adalah mengolah data dan menganalisis data yang cara-caranya sebagai berikut:

- Deduksi yaitu upaya memperoleh data yang bersifat khusus melalui penalaran dan penganalisisan data-data yang bersifat umum.

- Induksi upaya memperoleh data-data yang bersifat umum melalui penalaran dan penganalisasian terhadap data yang bersifat khusus.

- Menyandingkan beberapa keterangan atau data yang diperoleh untuk mendapatkan argumentasi yang lebih serta mampu memberikan kejelasan yang layak untuk dijadikan pegangan dalam penelitian.

\section{Prosedur Penelitian}

\section{- Perencanaan Tindakan}

Perencanaan Tindakan Sekolah dilakukan dengan penilaian terlebih dahulu terhadap kebutuhan-kebutuhan guru yang diperoleh dari informasi hasil pembicaraan dengan guru. Diperoleh kesimpulan bahwa guru memiliki keterbatasan dalam menyusun RPP. Permasalahan ini diangkat menjadi isu pembinaan dengan memberikan penyuluhan tentang penyusunan RPP.

\section{- Pelaksanaan Tindakan}

Setelah dilakukan penilaian terhadap RPP, dilakukan penyuluhan penyusunan RPP sesuai pedoman.

\section{- Observasi/Pengamatan}

RPP yang sudah disusun dilaksanakan dikelas dengan menggunakan instrumen.

\section{- Refleksi}

Tindakan-tindakan tersebut diimplementasikan dalam tiga siklus tindakan dan setiap siklus diakhiri dengan refleksi.

\section{PEMBAHASAN PENELITIAN}

\section{Deskripsi Persiklus}

Pelaksanaan PTS yang direncanakan oleh penulis dalam bentuk pelaksanaan Penelitian Tindakan Kelas dengan judul "Upaya Peningkatan Kinerja Guru Melalui Tekhnik Lesson Study Secara Kolaboratif dan Rutin Di 
Taman Kanak-kanak PURI INSANI Kota Jambi" berjalan sesuai dengan perencanaan PTS.

Hasil penelitian yang direfleksi dari permasalahan yang menjadi fokus penelitian menunjukan hasil yang membawa pengaruh positif pada guru. Terlihat dari hasil penelitian.

Hasil penilaian dapat terlihat pada tabel di bawah ini:

\section{REKAPITULASI HASIL PENILAIAN}

\begin{tabular}{|c|l|c|c|}
\hline \multirow{2}{*}{ No } & \multirow{2}{*}{ Nama } & \multicolumn{2}{|c|}{ Nilai Hasil Evaluasi } \\
\cline { 3 - 4 } 1 & SURYANTI & Siklus I & Siklus II \\
\hline 2 & EKA PRIHATINI, A.Md & 19 & 24 \\
\hline \multirow{2}{*}{3} & VERONICA, S.Pd.AUD & 20 & 23 \\
\hline \multirow{2}{*}{4} & ROSMAYANTI, S.Pd.AUD & 22 & 25 \\
\hline & JUMLAH & $\mathbf{8 0}$ & 24 \\
\hline & Rata-rata & $\mathbf{2 0}$ & $\mathbf{9 6}$ \\
\hline
\end{tabular}

Adapun dalam bentuk diagramnya adalah sebagai berikut:

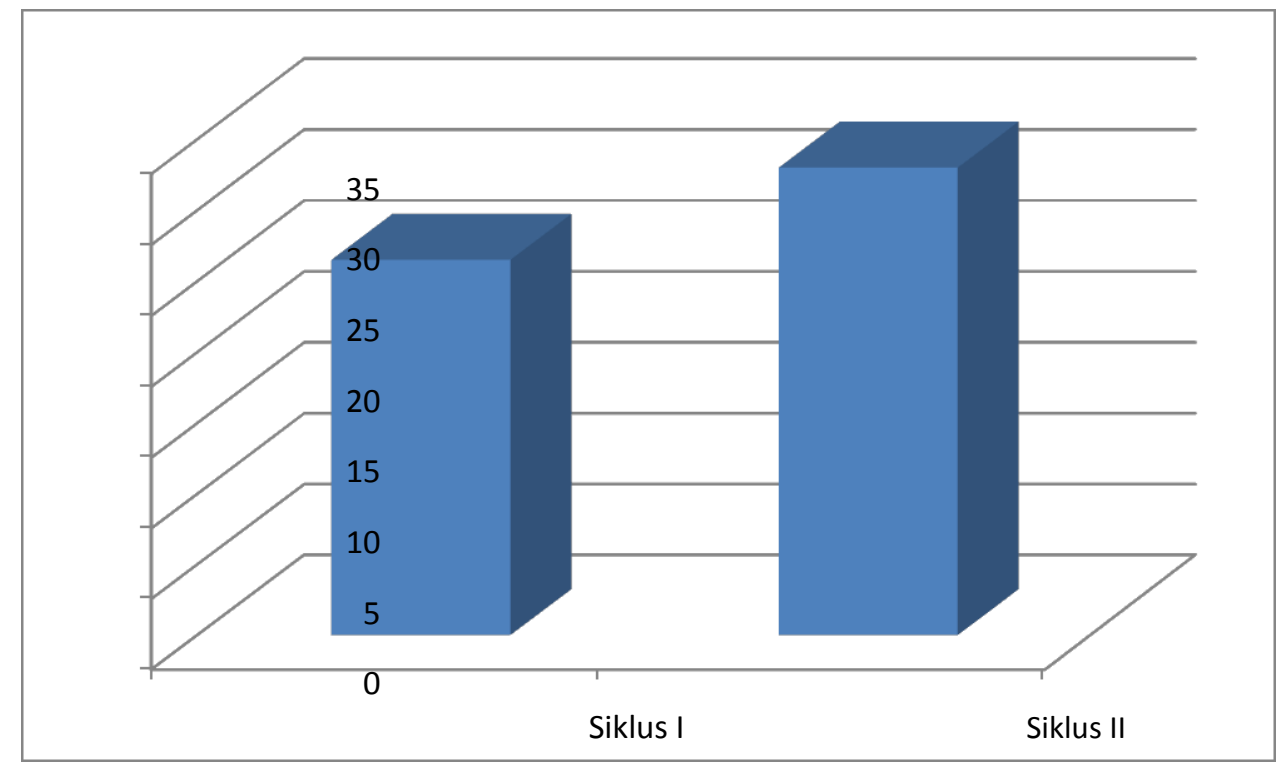


Keterangan :

Penguasaan guru dalam melakukan pembelajaran mengalami peningkatan dari siklus pertama ke siklus kedua setelah diberikan teknik short briefing secara rutin mengenai penyusunan RPP yang benar, materi pelajaran yang akan disampaikan dari siklus ke siklus.

Berdasarkan temuan-temuan yang didapat selama mengadakan penelitian terhadap pelaksanaan tugas sehari-hari sebagai kepala sekolah dan penerapan metode Lesson Study secara rutin sebelum guru melakukan tugas mengajar menunjukkan adanya peningkatan produktifitas, profesional dan mutu pembelajaran di kelas.

\section{Pembahasan Tiap Siklus}

Kondisi awal sebelum diterapkan metode Lesson Study secara rutin sebelum guru melakukan tugas mengajar menunjukkan:

1) Kurangnya kesadaran dan tanggung jawab guru akan tugas pokok dan fungsi yang dibebankan oleh pemerintah.

2) Kurangnya perencanaan yang matang dalam melaksanakan tugas dan belum siapnya guru untuk mengadakan perubahan kearah yang lebih maju sesuai dengan perkembangan dunia pendidikan.

3) Kurangnya pemahaman guru akan tugasnya sebagai agen pembelajaran.

4) Belum terbentuknya disiplin sekolah dan iklim budaya kerja sekolah yang mengacu pada peningkatan mutu pembelajaran.

Pemahaman guru terhadap tugas sebelum diterapkannya pendekatan tersebut adalah dalam melaksanakan tugasnya hanya mengandalkan persiapan seadanya bahkan kadang sama sekali tidak ada persiapan. Hal ini terjadi karena fungsi kontrol sebagai salah satu tugas kepala sekolah tidak berjalan sebagaimana mestinya. Di samping itu seolah-olah guru hanya sekedar melaksanakan tugas tanpa ada perancanaan yang matang dan tidak berpikir bagaimana hasil akhir setelah melaksanakan tugas mengajar. Dapat dibayangkan jika seorang kepala sekolah tidak mempunyai kemampuan untuk mengatur, memimpin, mengelola atau mengadministrasikan sumber daya 
meliputi perencanaan, pelaksanaan, pengawasan, dan pembinaan terhadap guru-guru sebagai bawahannya.

Teknik Lesson Study dikemas agar menarik, memukau dan apa yang kepala sekolah sampaikan langsung masuk dan dapat diaplikasikan dalam kegiatan pembelajaran oleh guru-guru. Pertama kali yang harus disadari adalah apa yang akan kita sampaikan. Kepala sekolah harus memahami visi sekolah. Visi sekolah akan menurunkan Misi yang sekolah buat dalam waktu yang pendek. Misi yang sekolah buat inilah yang akan menurunkan culture kerja. Culture kerja inilah yang kemudian akan memunculkan Motivasi kerja. Jadi dengan memahami Visi, kepala sekolah akan dapat menciptakan budaya kerja dalam tim sekolah dan sekaligus memunculkan motivasi personil.

Yang kedua, yang harus kepala sekolah sadari bahwa pada saat teknik Lesson Study dimulai, kepala sekolah harus menyadari secara sepenuhnya bahwa teknik ini adalah teknik yang berkesinambungan, yang akan membutuhkan waktu untuk bisa beradaptasi dengan teknik baru, maka diperlukan keuletan dan kesabaran dalam mengolah manajemen di sekolah. Strategi melaksanakan lesson study berdasarkan hasil penelitian penulis:

\section{Perencanaan (Plan)}

\section{- Identifikasi Masalah Pembelajaran}

1. Materi Ajar
a. kedalaman materi
b. kesesuaian dengan tuntutan kurikulum
c. tingkat kesulitan

2. Strategi Pembelajaran
a. Pendahuluan
Memotivasi siswa belajar
b. Kegiatan inti

3. Penutup

Aktivitas siswa yang diharapkan untuk menyimpulkan pelajaran

\section{- Mempersiapkan Perangkat Pembelajaran}

1. Silabus 
2. Rencana Pelaksanaan Pembelajaran

3. Lembar Kegiatan Siswa

4. Alat tes

- Menentukan Observer

1. Kepala Sekolah

2. Guru

3. Pengawas Sekolah

- Menentukan Guru Model (pelaksana pembelajaran di kelas)

\section{Pelaksanaan $(D o)$}

a. Pertemuan singkat (briefing) dipimpin fasilitator (kepala sekolah).

b. Guru model mengemukakan rencana singkat (rencana pembelajaran, tujuan, kedudukan materi ajar dalam kurikulum, perkiraan kemungkinan respon siswa).

c. Kepala sekolah mengingatkan observer untuk tidak mengintervensi proses belajar mengajar.

d. Observer dipersilahkan memilih tempat strategis sesuai rencana pengamatan.

e. Guru model melaksanakan proses belajar mengajar.

\section{Observasi}

Observer membuat catatan tentang:

a. Komentar siswa dalam diskusi.

b. Kerja sama siswa.

c. Aktivitas belajar.

d. Strategi penyelesaian masalah.

Pedoman observer:

a. Kejelasan tujuan pembelajaran.

b. Aktivitas mengarah ke pencapaian tujuan.

c. Langkah-langkah pembelajaran berkaitan mendukung pemahaman siswa.

d. Media pembelajaran mendukung pencapaian tujuan. 
e. Diskusi kelas membantu pemahaman konsep.

f. Materi ajar sesuai tingkat kemampuan siswa.

g. Penggunaan pengetahuan awal untuk mendukung pemahaman konsep.

h. Pertanyaan guru mendorong dan memfasilitasi cara berpikir siswa.

i. Pemberian penghargaan gagasan siswa.

j. Kesimpulan didasarkan pendapat siswa.

k. Kesimpulan sesuai tujuan.

1. Pemberian penguatan.

\section{Refleksi (See)}

b. Menentukan fasilitator.

c. Fasilitator mengenalkan observer dengan spesifikasi bidang ilmu.

d. Fasilitator menyampaikan agenda refleksi.

e. Fasilitator menyampaikan aturan main.

- Berbicara dengan tertib (jadi pendengar yang baik)

- Berbicara sopan tidak untuk mengadili guru model

- Setiap peserta diberi kesempatan berbicara

- Berbicara berdasarkan temuan pengamatan

- Masukan difokuskan pada "bagaimana siswa belajar"

f. Guru model menyampaikan:

- Kejadian yang sesuai dan yang tidak sesuai dengan harapan.

- Sesuatu yang berubah dari rencana.

g. Team pengembang memberi komentar.

h. Fasilitator memberi kesempatan observer berkomentar

i. Fasilitator mempersilahkan tenaga ahli merangkum diskusi.

j. Fasilitator mengucapkan terimakasih dan mengumumkan kegiatan lesson study berikutnya.

\section{E. KESIMPULAN DAN SARAN}

\section{Kesimpulan}

Berdasarkan pembahasan hasil penelitian yang telah dilakukan dalam bab sebelumnya melalui "Upaya Peningkatan Kinerja Guru Melalui Teknik 
Lesson Study Secara Kolaboratif dan Rutin Di Taman Kanak-kanak PURI INSANI Kota Jambi" dapat ditarik kesimpulan, sebagai berikut:

a. Pelaksanaan program yang rutin dan berkesinambungan merupakan kunci keberhasilan dalam melaksanakan tugas sebagai kepala sekolah dalam meningkatkan mutu pembelajaran di kelas.

b. Pada "Upaya Peningkatan Kinerja Guru Melalui Teknik Lesson Study Secara Kolaboratif dan Rutin Di Taman Kanak-kanak PURI INSANI Kota Jambi" ternyata mampu membentuk tenaga pendidik yang produktif/ profesional dan mampu meningkatkan mutu pembelajaran.

c. Dengan adanya terobosan dan inovasi melalui pendekatan "Upaya Peningkatan Kinerja Guru Melalui Teknik Lesson Study Secara Kolaboratif dan Rutin Di Taman Kanak-kanak PURI INSANI Kota Jambi " ternyata ada pengaruh yang besar terhadap hasil belajar siswa.

\section{Saran}

Berdasarkan kesimpulan di atas, guru dituntut untuk melaksanakan beberapa hal dalam meningkatkan kualitas pembelajaran, khususnya dalam meningkatan penguasaan materi pelajaran dan keaktifan siswa dalam belajar.

Adapun hal-hal yang harus dilakukan guru diantaranya :

- Menentukan tujuan pembelajaran (lesson) satuan (unit) pelajaran, dan mata pelajaran yang efektif.

- Mengkaji dan meningkatkan pelajaran yang bermanfaat bagi siswa.

- Memperdalam pengetahuan tentang mata pelajaran yang disajikan para guru.

- Menentukan tujuan jangka panjang yang akan dicapai para siswa.

- Menentukan pelajaran secara kolaboratif.

- Mengkaji secara teliti belajar dan perilaku siswa.

- Mengembangkan pengetahuan pembelajaran yang dapat diandalkan.

- Melakukan refleksi terhadap pengajaran yang dilaksanakannya berdasarkan pandangan siswa dan koleganya. 


\section{DAFTAR PUSTAKA}

Hendayana S.. 2006. Lesson Study Suatu Strategi untuk Meningkatkan Keprofesionalan Guru (Pengalaman JUSTEP-JICA). Bandung: UPI Press.

Parmin dan Siti Aminah. 2008. Menerapkan Lesson Study Dalam Pembelajaran di MI Madariful Huda Pati. Laporan Penelitian Dosen Muda. FMIPA: Universitas Negeri Semarang.

Widhiartha, Putu Ashintya. Dwi Sudarmanto. Nining Ratnasingsih. 2008. Lesson Study Sebuah Upaya Peningkatan Mutu Pendidik Pendidikan Non Formal. Surabaya: Prima Printing.

Yusak, Muchlas. 2008.LessonStudy: Pengembangan Profesi Guru Secara Berkelanjutan Berbasis Sekolah. Semarang: LPMP Jawa Tengah.

http://www.slideshare.net/aminhers/lesson-study, Lesson Study-Presentation Transcript, 2010

Rika Ariyani, Editor Jurnal Literasiologi. Literasi Kita Indonesia. STAI Syekh Maulana Qori.

Hidayat, H., \& Sumarto, S. (2018). Urgensi Pembukaan Unit Layanan Pendidikan Bimbingan dan Konseling (BK) di Setiap Program Studi Fakultas Ilmu Tarbiyah dan Pendidikan UIN Sulthan Thaha Saifuddin Jambi. Jurnal Al-Ashlah, 2(2). Diambil dari https://journal.staimaarif jambi.ac.id/index.php/alashlahjournal/article/view/141

Sumarto, S. (2017). Equalization and Standardization of Management of Education in Madrasah. HUNAFA: Jurnal Studia Islamika, 14(1), 117-139. https://doi.org/10.24239/jsi.v14i1.450.117-139 